\title{
Broad spectrum antibacterial activity of granaticinic acid, isolated from Streptomyces thermovi daceus NT1; an endophyte in Catharanthus roseus (L.) G. Don
}

\author{
Sudipta Roy ${ }^{1}$, Debdulal Banerjee ${ }^{2}$ \\ ${ }^{1}$ Department of Microbiology, Vidyasagar University, Midnapore- 721102, West Bengal, India. \\ ${ }^{2}$ Department of Botany, Vidyasagar University, Midnapore- 721102, West Bengal, India.
}

\begin{tabular}{l}
\hline ARTICLE INFO \\
\hline Article history: \\
Received on: 28/03/2015 \\
Revised on: 20/04/2015 \\
Accepted on: 01/07/2015 \\
Available online: $27 / 07 / 2015$ \\
\hline Key words: \\
Endophyte, Streptomyces \\
thermoviolaceus, granaticinic \\
acid, antibacterial, drug \\
resistance. \\
\hline
\end{tabular}

\section{INTRODUCTION}

Screening of antimicrobial compound producing microorganisms is a continual field of research and actinomycetes are playing a promising role as the source of such compounds. Over two third of present day antibiotics were obtained from Streptomyces (Baltz, 1998), a special group within actinomycetes but presently isolation of such compounds are unable to meet the demand for a new class of bioactive compounds. Moreover emergence of drug resistant pathogens, outbreak of opportunistic bacteria and throttle success of combinatorial chemistry creates the situation more severe (Strobel, 2003). Endophytic microorganisms have taken this opportunity as a good source of future antimicrobial compounds. Endophytes reside within the plant's internal tissues which are still less explored ecosystem harboring diverse microbes. Some of them act synergistically by producing secondary metabolites

\footnotetext{
* Corresponding Author

Debdulal Banerjee, Department of Botany, Vidyasagar University, Midnapore-721102, West Bengal, India. Email: debu33@gmail.com
}

antagonistic to plant pathogens (Strobel and Daisy, 2003) or by producing plant growth promoting substances (Bhattacharya and Jha, 2012).

Actinomycetes are also found in endophytic association like fungi (Kharwar et al., 2008) and other bacteria and can serve as a prime source of novel class antimicrobial compounds, as chances of getting new compound is relatively higher from new strain and isolation of new strain is advantageous from unexplored or less explored habitat (Stierle et al., 1993). Several studies describe the isolation and identification of endophytic actinomycetes producing metabolites against fungal plant pathogens but few are reported against bacterial pathogens especially drug resistant or opportunistic bacterial pathogens (Castillo et al., 2002; Castillo et al., 2003; Taechowisan et al., 2005, Taechowisan et al., 2014).

Present study illustrates the isolation and identification of endophytic Streptomyces thermoviolaceus NT1 from Catharanthus roseus. Purification of metabolites produced by this strain afforded granaticinic acid, which showed broad spectrum antibacterial property and was also active against drug resistant pathogens. 


\section{MATERIALS AND METHODS}

\section{Endophytic actinomycetes isolation}

Healthy and young plants of Catharanthus roseus (L.) G. Don. were collected from various places of Psachim Medinipur, India $\left(22.57^{\circ} \mathrm{N}-87.11^{\circ} \mathrm{E}\right)$. Stems (about $1 \mathrm{~cm}$ length) of $C$. roseus were surface sterilized by sequential ethanol and $\mathrm{NaOCl}$ treatment and finally washed three times with autoclaved distilled water (Coombs and Franco, 2003).

Authenticity of surface sterilization was verified by plating the final sample washed water on nutrient agar media. The bark was removed of samples and tissues were soaked in $10 \%$ $\mathrm{NaHCO}_{3}$ for 5 min to suppress fungal contamination. Inner tissues were then aseptically transferred to ISP2, ISP5 (International Streptomyces Project) agar and actinomycetes isolation agar media (Himedia, Mumbai) supplemented with cycloheximide and streptomycin $(50 \mu \mathrm{g} / \mathrm{ml})$. Plates were incubated at $28{ }^{\circ} \mathrm{C}$ for 14 days. Isolated strains were pure cultured and preserved in glycerol based liquid media at $-20^{\circ} \mathrm{C}$.

\section{In vitro antimicrobial assay}

Isolated strain, NT1 was checked for Antimicrobial potency by agar diffusion methods. This strain was grown in ISP2 broth and $100 \mu \mathrm{l}$ cell free cultures was applied in wells of Muller Hinton agar media that was previously seeded with bacterial pathogens. Inhibition zones were recorded after $24 \mathrm{~h}$ incubation at $35^{\circ} \mathrm{C}$ for each pathogen.

Following pathogenic bacteria were selected in this study: methicillin resistant Staphylococcus aureus, penicillin resistant Staphylococcus aureus (clinical isolate), Bacillus subtilis (ATCC 11774), Bacillus cereus (ATCC 14579), Vibrio parahemolyticus ATCC 1782, Pseudomonas aeruginosa (ATCC 9027), Shigella flexnerii (ATCC 12022), and Escherichia coli (clinical isolate).

\section{Morphological, physiological and biochemical characterizations}

Characterization of the strain was done based on cultural characteristics, morphological, physiological and biochemical properties. Cultural morphology was established after growing the organism at various media (Shirling and Gottlieb, 1966; Williams et al., 1983) and cellular morphology was determined by the compound and scanning electron microscopy (Vega $\odot$ TESCAN, Czech Republic). Extracellular enzyme production and sugar utilization test (Gordon et al., 1974) were made by standard methods. The strain was grown in ISP 2 broth at various incubation temperature and $\mathrm{pH}$ conditions for determining its optimum growth temperature and $\mathrm{pH}$ requirement.

\section{Genomic DNA isolation and amplification of 16s rRNA gene}

Cells were lysed of 5 days old culture by lysozyme and SDS treatment $(5 \mathrm{mg} / \mathrm{ml}$ and $10 \%$ respectively). Genomic DNA was extracted with phenol-chloroform and precipitated with isopropanol. Finally genomic DNA was dissolved in $100 \mu \mathrm{TE}$
$(\mathrm{pH} 8)$ buffer. The 16s rRNA gene was amplified using the primers 27F (5'-AGAGTTTGATCCTGGCTCAG-3') and 1492R (5'-GGTTACCTTGTTACGACTT-3') (Santhi and Solomon, 2011) in a thermocycler (Eppendorf). PCR products were purified with Hi-PurA $^{\mathrm{TM}}$ PCR product purification spin kit (Himedia Laboratories, India). Forward and reverse DNA sequencing of amplicon was carried out with the same primers using BDT v3.1 Cycle sequencing kit on ABI 3730xl Genetic Analyzer.

\section{Phylogeny construction and sequence submission}

Consensus sequences of 1412 bp rRNA gene were edited and assembled from forward and reverse sequence data using aligner software. The $16 \mathrm{~S}$ rRNA gene sequence was used to carry out BLAST with the 'nr' database of NCBI Genbank to determine operational taxonomic units. Based on maximum identity score sequences were selected and aligned using the multiple alignment software program, Clustal W. Distance matrix was generated using RDP (Ribosomal Database Project) database and the phylogenetic tree were constructed using MEGA 6 (Tamura et al., 2007) (Molecular Evolutionary Genetics Analysis). The evolutionary history was inferred using the Neighbor-Joining method (Saitou and Nei, 1987).

The evolutionary distances were computed using the Kimura 2-parameter method (Kimura, 1980). DNA sequences were deposited in GenBank under accession number KJ486841.1

\section{Antimicrobial production at optimum conditions}

Optimization of antibacterial production from NT1 was done by culturing it in various physical and chemical conditions. The strain was grown in a wide range of media $\mathrm{pH}(5-10)$ and incubation temperature $\left(20-45{ }^{\circ} \mathrm{C}\right)$. Optimum values were determined by measuring zone of inhibition produced by culture filtrates of each variant against $B$. cereus. Optimum additional carbon source was determined by adding glucose, galactose, fructose, maltose, lactose and sucrose (1\%, w/v) in ISP2 broth. Tryptone, peptone, soya meal $\left(0.5 \%\right.$, w/v), $\mathrm{KNO}_{3} \mathrm{NH}_{4} \mathrm{NO}_{3}$ and $\mathrm{NH}_{4} \mathrm{Cl}$ were additionally $(0.2 \%$, w/v) added to the ISP broth to find most suitable nitrogen source for antibacterial production by the strain NT1.

A $1 \mathrm{~cm}$ diameter agar plug, full of NT1 spores was inoculated in $30 \mathrm{ml} \mathrm{ISP} 2$ broth and cultured at $28^{\circ} \mathrm{C}$ for 3 days. 5 $\%$ culture was transferred to $100 \mathrm{ml}$ ISP2 broth in $500 \mathrm{ml}$ conical flask and cultured for 3 days more and used as seed for next step larger production. Finally, $5 \%$ seed was inoculated in $1.5 \mathrm{~L}$ ISP2 broth and cultured for 10 days at $28^{\circ} \mathrm{C}$ with $150 \mathrm{rpm}$. Cell mycelia were separated by filtration with Whatman paper No. 1 and then centrifuged at $12000 \mathrm{rpm}$ for $15 \mathrm{~min}$. to obtain a cell free culture medium. Culture filtrate was extracted with equal volume ethyl acetate and organic fraction was made water free by adding sufficient anhydrous $\mathrm{Na}_{2} \mathrm{SO}_{4}$. It was then dried under vacuum in a rotary evaporator at $40{ }^{\circ} \mathrm{C}(\mathrm{HS}-2005 \mathrm{~S}$, HAHNSHIN, Korea) and antibacterial activity was determined by disk diffusion assay. 


\section{Purification of active component}

Residual crude was dissolved in $5 \mathrm{ml}$ chloroform, adsorbed by Silica gel and loaded onto a silica gel column (230$400 \AA$ mesh). It was then fractionated with graded hexane chloroform $(60: 0,50: 10,30: 30,10: 50,0: 60)$ and then with chloroform-methanol (60:0, 55:5, 50:10, 40:20, 30:30, 20:40, $0: 60)$. About $60 \mathrm{ml}$ of each fraction was collected. Fractions were concentrated and checked for antibacterial property by disk diffusion technique on MHA plates. Active fraction was refractioned with more finely graded solvent system (chloroform and methanol; 60:0, 59:1, 58:2, 57:3, 56:4, 55:5, 50:10, 0:60) and active fraction was determined by similar assay.

\section{TLC and bioautogram analysis}

Purified fraction was concentrated and analyzed by thin layer chromatography with chloroform and methanol (5:1). Separated components were located on UV exposure. Autobiogram was done with $B$. cereus to find active component on TLC plates. After TLC analysis the plate was overlaid with molten MHA media $\left(45^{\circ} \mathrm{C}\right)$ containing $50 \mu \mathrm{l}$ aliquots of $B$. cereus $\left(10^{6}\right.$ $\mathrm{cfu} / \mathrm{ml}$ ). TLC plate was incubated at $37{ }^{\circ} \mathrm{C}$ overnight and inhibition zone was located by methylthiazoletetrazolium (MTT-5 $\mathrm{mg} / \mathrm{ml})$.

\section{Spectroscopic analysis of active compound}

Structural information of active component was gathered by UV, IR, NMR, and mass spectral data. $\lambda_{\max }$ was determined of active compound after dissolving in chloroform by UV-Vis spectrophotometer (UV-1800, SHIMADZU). FTIR spectra were taken in FT-IR spectrophotometer (Spectrum T, Perkin Elmer). The sample was dissolved in $\mathrm{CDCl}_{3}$ and analyzed for ${ }^{1} \mathrm{H}$ and ${ }^{13} \mathrm{C}$ NMR spectra at $600 \mathrm{MHz}$ (Bruker, Avance 600). ESI Mass was analyzed with positive ion mode.

\section{RESULTS AND DISCUSSIONS}

The isolated endophytic strain was gram positive, filamentous actinobacteria that grow well aerobically. Substrate mycelia nicely emerge within 3 day after inoculation and aerial formations were grey that turns to white. The strain produces soluble violet pigment in ISP2 media. It produced slow-growing, dry and hard colonies on ISP2 agar. Scanning electron microscopy of the organism revealed the presence of numerous aerial filaments and few smooth, cylindrical spores $(0.8 \mu \mathrm{m}$ in length and $0.2 \mu \mathrm{m}$ in diameter) that were produced in short curved (Fig. 1).

Other morphological, and biochemical properties of strain NT1 were summarized in table 1. Comparative 16S rRNA gene sequence analysis (Fig. 2) showed that the strain was taxonomically belong to the species of Streptomyces and highest similarities being found with the sequences of Streptomyces thermoviolaceus (AB184685.1), Streptomyces thermocyaneomaculatus (AB184583.1), Streptomyces thermocyaneoviolaceus (AB184582.1), Streptomyces thermophilus
Table 1: Cultural and physiological characteristics of endophytic Streptomyces themoviolaceus NT1.

\begin{tabular}{ll}
\hline Colony morphology & $\begin{array}{l}\text { Elevated, rough surface, dry, brownish to } \\
\text { white colony }\end{array}$ \\
\hline Growth on ISP2 & Good \\
Substrate mycelia & Brownish \\
Aerial mycelia & White \\
Soluble pigment & Redish violet \\
\hline Growth on ISP4 & Moderate \\
Substrate mycelia & Yellowish \\
Aerial mycelia & White \\
Soluble pigment & Violet \\
\hline Growth of ISP5 & Very less \\
Substrate mycelia & Gray \\
Aerial mycelia & White \\
Soluble pigment & No \\
\hline Growth on ISP7 & Very poor \\
Substrate mycelia & Yellowish \\
Aerial mycelia & White \\
Soluble pigment & No \\
\hline Spore morphology & $3-5$ spores at tip of the filaments Cylindrical, \\
& smooth surface About 0.8 to0.2 $\mu$ m diameter \\
\hline Cell morphology & Highly branched filamentous, Gram positive \\
\hline Extra cellular & Cellulase, amylase, protease (+) \\
enzymes & \\
\hline Carbon source & Dextrose, fructose, galactose, lactose, maltose, \\
utilization & sucrose, starch, mannitol $(+)$, xylose, inositol, \\
& rhamnose $(-)$ \\
\hline Growth temperatue & \\
$20^{\circ} \mathrm{C}$ & - \\
$28^{\circ} \mathrm{C}$ & ++ \\
$35^{\circ} \mathrm{C}$ & $++($ optimum*) \\
$40^{\circ} \mathrm{C}$ & - \\
\hline Growth pH & - \\
5 & + \\
6 & ++ (optimum*) \\
7 & + \\
8 & + \\
9 & - \\
10 & \\
\hline & \\
\hline
\end{tabular}

(*Optimum has been determined as mean of triplicate study).

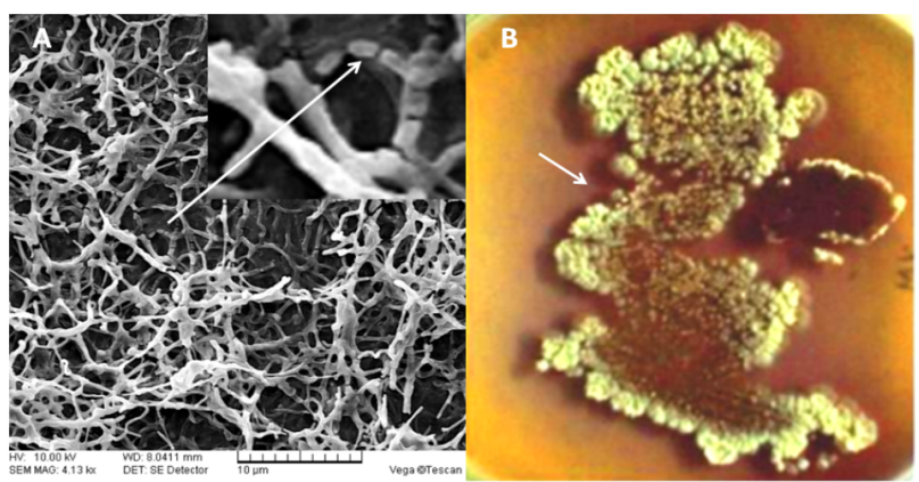

Fig. 1: Endophytic Streptomyces thermoviolaceous NT1; A: SEM view (arrows indicate spores, magnified view), B - colony morphology on ISP2 (arrow indicate redish violet pigmentation).

(AB184358.1) about $99 \%$ and with Streptomyces thermodiastaticus (AJ001434.1), Streptomyces sp. E1125 (DQ303453.1), Streptomyces sp. SDCB6 (JN617215.1) 98\%. It is evident from the phylogenetic tree based on the neighbor-joining method that the strain NT1 clusters with the nearest neighbors $S$. thermoviolaceus NBRC 13387 in a separate branch with high bootstrap support. 


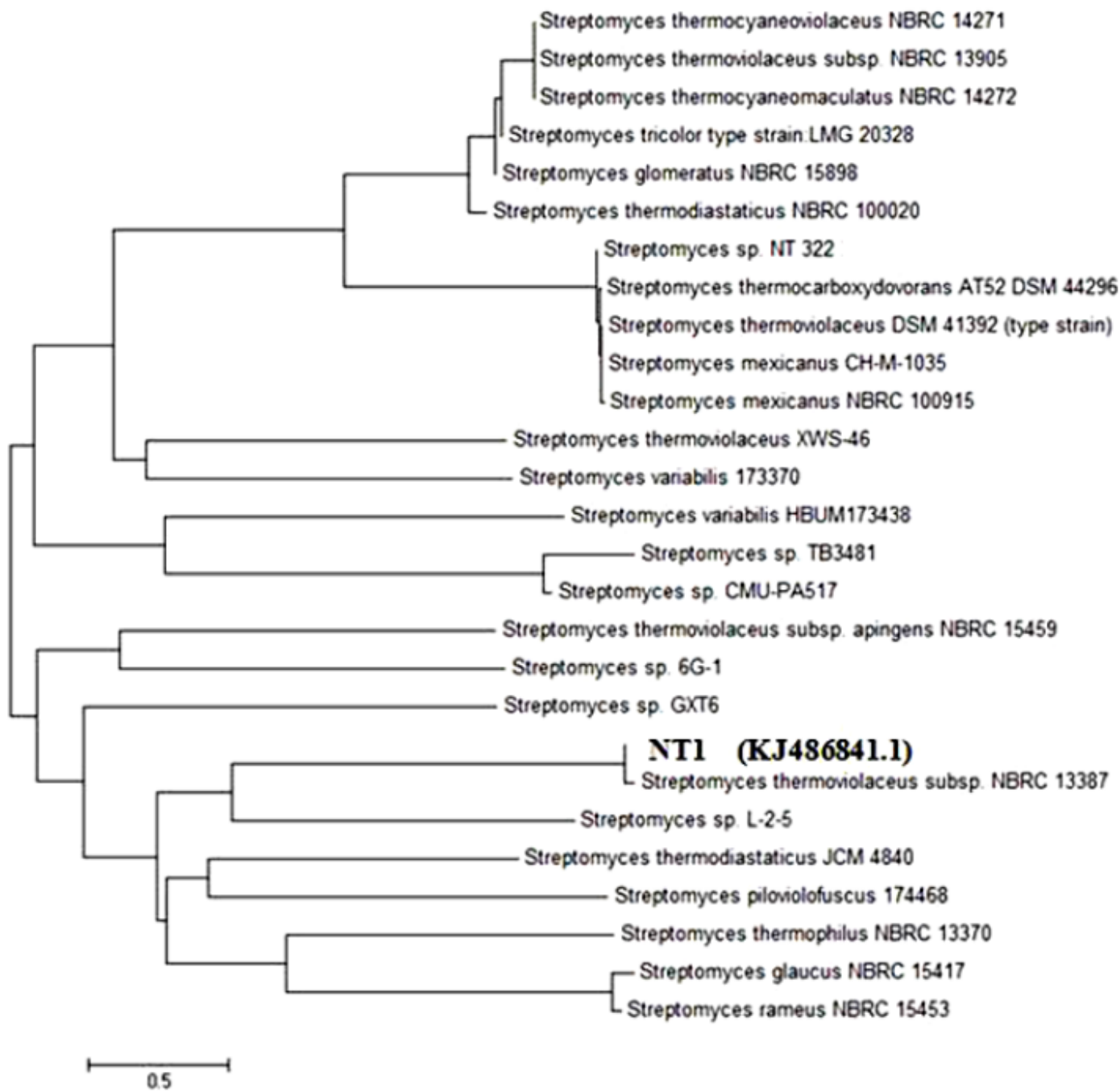

Fig. 2: Neighbor-joining tree based on 16s ribosomal RNA gene sequences showing relationship between NT1 and members of the genus Streptomyces.

Table. 2: Pathogen growth inhibition by NT1 culture filtrate and column purified active fraction.

\begin{tabular}{|c|c|c|c|c|c|c|c|c|}
\hline \multirow{2}{*}{ Sample } & \multicolumn{8}{|c|}{ Zone inhibition $(\mathrm{mm})$ ( Results are represented as means \pm standard deviation of three replicates ) } \\
\hline & PRSA & MRSA & B. cereus & B. subtilis & V.parahemolyticus & P. aeruginosa & S. flexnerii & E. coli \\
\hline Culture filtrate $\dagger$ & $13.6 \pm 0.5$ & $13 \pm 0.8$ & $17.3 \pm 1$ & $18 \pm 0.4$ & $9.6 \pm 0.9$ & $8.83 \pm 0.8$ & $10.5 \pm 1.4$ & $12.5 \pm 1$ \\
\hline Crude extract\# & $29.3 \pm 1.2$ & $27.6 \pm 1.2$ & $30.8 \pm 2$ & $33 \pm 0.9$ & $13 \pm 0.5$ & $16.3 \pm 0.8$ & $19.8 \pm 0.4$ & $15 \pm 0.6$ \\
\hline
\end{tabular}

$\dagger$, At the amount of $100 \mu$ l of 14 days old culture supernatant in agar well.

$\#$, At the amount of $25 \mu 1$ on paper discs soaked with tested substance.

The strain fitted, in all respects, the taxonomic position within genus Streptomyces. Cellular and colony morphology, soluble pigments on media and biochemical characterization like enzyme profile and molecular characterization strongly suggest our isolate to be a new strain, Streptomyces thermovilaceous NT1. Few or modest spore production was found from this isolate in different media may be due to some biochemical relationship with its host plant. Previous isolates of this bacterium were of thermophilic range that could be cultivated at $50{ }^{\circ} \mathrm{C}$ with antimicrobial production (James and Edwards, 1989) but NT1 does not grow over $40{ }^{\circ} \mathrm{C}$. Internal plant tissue is a specialized ecosystem may be responsible of such alteration in gene sequence during co-evolution (Germaine et al., 2004).
Here is the opportunity of getting variations in metabolites from similar micro-organism isolated from other common habitats. Surprisingly an endophytic fungus, Fusarium oxysporum of $C$. roseus was interestingly found to produce vinblastine and vincristine the same natural products as host plants which opens a new probability in drug discovery (Kumar et al., 2013).

The isolated endophytic strain may be a good source for the antimicrobial compound due to its broad spectrum antibacterial property and its potency against drug resistant pathogens. Culture filtrate of endophytic $S$. thermoviolaceus NT1 showed broad spectrum antibacterial activity to all selected pathogens. Table: 2 represent inhibition zones produced by culture filtrate and crude ethyl acetate extract against test pathogenic bacteria. It was found 
that the antimicrobial compound was more effective for Gram positive bacteria than Gram negative bacteria. S. thermoviolaceus WR-141, a previous isolate of non-endophytic origin (St. Pyrek et al., 1977) was found to produce antimicrobial that solely inhibited Gram positive.

The NT1 is also active against $P$. aeruginosa, an opportunistic pathogen that has become a major cause of nosocomial infections worldwide and a serious issue of public health. Moreover, only a few drugs are available to treat very serious infection of drug resistant Staphylococci. In this regard anti MRSA and anti PRSA activity of this strain indicates its promising role in future drugs. It was found that this strain produced the antibacterial substance best level at media $\mathrm{pH}-7$, and $35^{\circ} \mathrm{C}$ (Fig. 3) with $1 \%$ additional glucose and tryptone $(0.5 \%)$. In a separate experiment, $S$ thermoviolaceous NCIB 10076 was found to produce antibacterial substances optimally at $\mathrm{pH}-7$ and at $45{ }^{\circ} \mathrm{C}$ incubation temperature (James and Edwards, 1989).
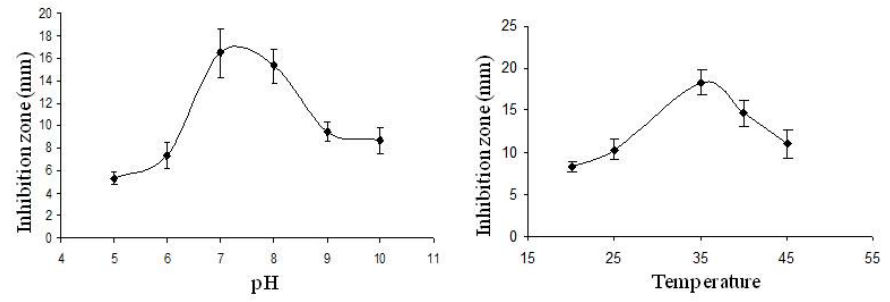

Fig. 3: Most suitable $\mathrm{pH}$ and temperature for optimum antibacterial production by NT1.

Fig. 4: Thin layer chromatography and autobiogram analysis of purified substance. Arrows indicate presence of active component.

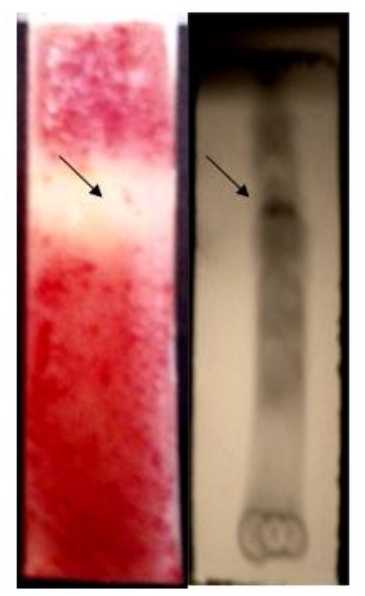

After repeated column chromatography and activity guided TLC purification (Fig. 4), the active compound was found as amorphous red substance and changes its color from red to blue by $\mathrm{pH}$ change. It absorbs UV strongly with UV $\lambda_{\max }\left(\mathrm{CHCl}_{3}\right) \mathrm{nm}$ (log ع) 223 (1.3), 236 (0.32), 523 (1.24), 558 (1.32), 612 (1.43); IR $v_{\max }$ were found with $(\mathrm{KBr}) \mathrm{cm}^{-} 1: 3600 \sim 3400,3000 \sim 2850$, 1712, 1665, 1610, 1458 (Fig. 3); MS m/z (relative intensities): $463.26[\mathrm{M}]^{+} ;{ }^{1} \mathrm{H}$ NMR $\left(\mathrm{CDCl}_{3}\right) \delta 7.812$ (doublet, $j=7.8 \mathrm{~Hz}$ ), 7.714 (doublet, $j=5.4$ ), 7.541 (triplet, $J_{l}=J_{2}=7.2 \mathrm{~Hz}$ ), 7.455 (triplet, $J_{l}$ $=J_{2}=7.8 \mathrm{~Hz}$ ), 7.269, 6.427 (doublet, $j=5.4$ ), 3.648, 3.597, 2.374, $1.471-0.843$; $13 \mathrm{C}$ NMR $\left(\mathrm{CDCl}_{3}\right) \delta 170.11$ (-COOH), 154.26,
132.13, 129.07, 128.63, 127.34 (C aromatic), 113.04 (C), 42.44, $41.23(\mathrm{CH}), 35.01,34.05,33.70,31.90,29.67,29.14,27.18,24.82$, $22.67\left(\mathrm{CH}_{2}\right), 19.47,18.81,14.10,11.25\left(\mathrm{CH}_{3}\right)$ (Fig. 5).
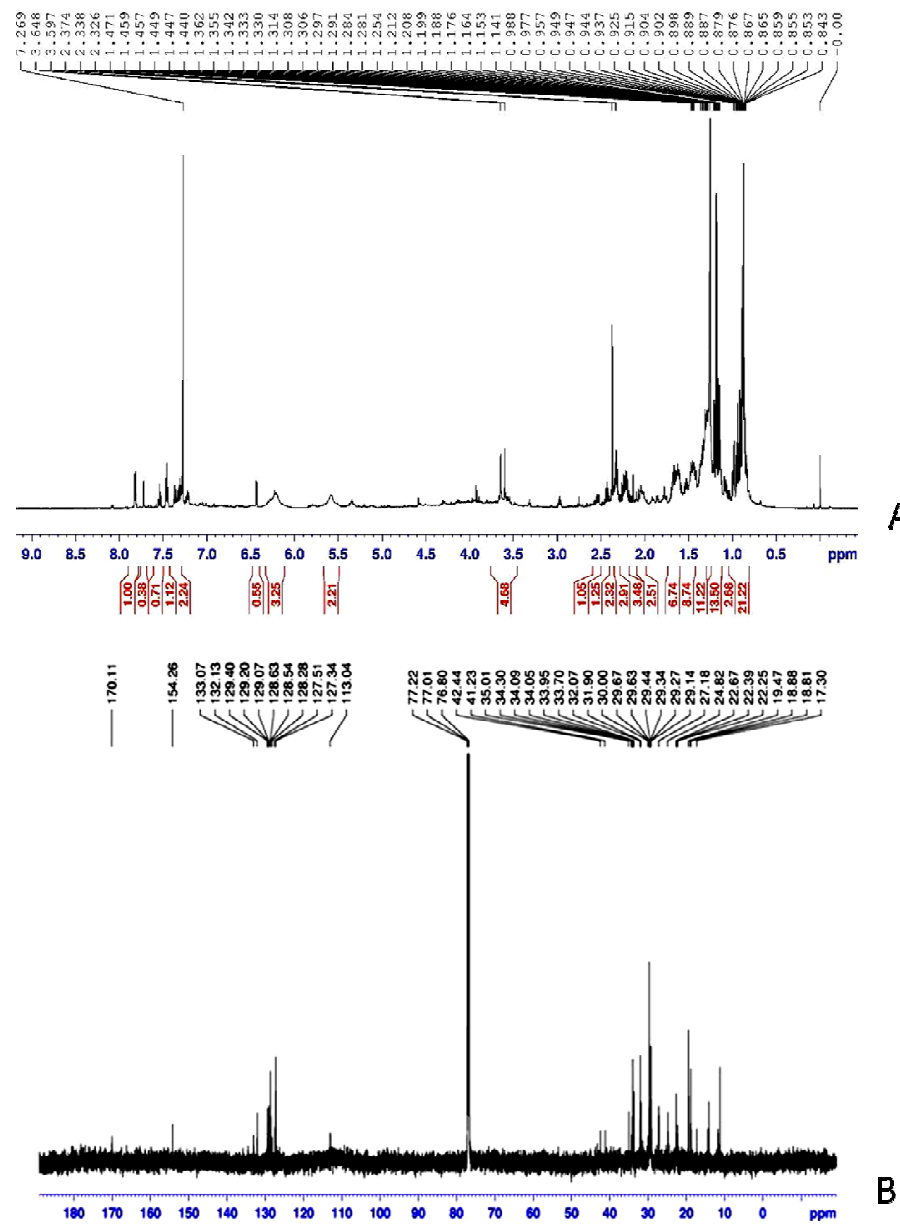

Fig. 5: NMR spectra of active antibacterial substance; A- ${ }^{1} \mathrm{H}$ spectra, B- ${ }^{13} \mathrm{C}$ spectra.

Granaticins are a series of polyketide-derived pyranonapthoquinone antibiotics (Fleck et al., 1980). UV absorbance at $223 \mathrm{~nm}$ is the most important measurement of granaticin like compound, beside that granaticin absorbs 285, 410, 490, 525 and $562 \mathrm{~nm}$ dissolved in an acidified ethanol $(0.1 \mathrm{M} \mathrm{HCl}$ in ethanol) (James and Edwards 1989). Similar UV absorbances were recorded at 223, 236, 523, 558, and $612 \mathrm{~nm}$ for compound dissolved in chloroform. Granaticin B contain L-rhodinose sugar moiety with granticin A which is absent in Granaticinic acid and concomitant $\gamma$-lactone cleavage of Granaticn A lead to the formation of granaticinic acid (St. Pyrek et al., 1977). Granaticinic acid is a red pigmented amorphous substance and changes its color with change of $\mathrm{pH}$. This compound with the molecular formula, $\mathrm{C}_{22} \mathrm{H}_{22} \mathrm{O}_{11}$ and molecular weight, 462.41 were isolated from a thermophilic Streptomyces sp. XT-11989 (Maehr et al., 1979) along with granaticin ( $\mathrm{Mr}$ 444.39). Mass analysis of purified substance in this study represent $463.26\left[\mathrm{M}^{+} \mathrm{H}\right]$ for granaticinic acid solely and no other masses related to granaticin or its other 
derivative were noticed in the spectrum. The IR spectrum shows typical $\mathrm{OH}$ stretching vibrations of the phenolic and carboxylic acid at $3600-3400$ and $3000-2850 \mathrm{~cm}^{-1}$. Peak at $1715 \mathrm{~cm}^{-1}$ is indicative of carbonyl vibrations of a saturated aliphatic carboxylic acid, which is also similar to granaticinic acid reported (US patent). IR absorbance at $1610 \mathrm{~cm}^{-1}$ is indicative of quinine carbonyl with strong intermolecular hydrogen bonds. In ${ }^{1} \mathrm{H}$ NMR, $\delta 7.269$ strongly suggest the presence of $\mathrm{p}$ - disubstituted aromatic, $\delta 2.374$ indicates $\mathrm{H}$ of adjacent carbon to carboxyl group and $\delta$ $1.471-0.843$ suggest the presence of $\mathrm{H}$ in primary or secondary aliphatic carbon. $\delta 170.11$ in ${ }^{13} \mathrm{C}$ NMR clearly represent for a $\mathrm{C}=\mathrm{O}$ in acid group where as $\delta 154.26$ stands for $=\mathrm{C}<$ in aromatic ring structure. So all physical and spectral evidences confirmed that the active antibacterial component is granaticinic acid produced by $S$. thermoviolaceus NT1.

\section{CONCLUSION}

This study demonstrates isolation of a new strain Streptomyces thermoviolaceus NT1 that colonized the inner tissues of $C$. roseus. It also proposes that the strain might be a significant source of antibacterial compound. Granaticinic acid was a major active component in cell free culture filtrate of NT1 which showed effective antagonism to drug resistant pathogens. This is the first report of isolation and identification of an endophytic (stems of $C$. roseus) Streptomyces thermoviolaceus producing granaticinic acid.

\section{ACKNOWLEDGEMENT}

Authors are thankful to University Grants Commission (UGC), New Delhi for funding, SR is thankful to Oriental Institute of Science and Technology (OIST) for their help during this work.

\section{REFERENCES}

Baltz RH. Genetic manipulation of antibiotic-producing Streptomyces. Trends Microbiol. 1998; 6, 76-83.

Bhattacharya PN, Jha DK. Plant growth promoting rhizobacteria (PGPR) emergene in agriculture. World J Microbiol Biotechnol, 2012; 28:1327-1350.

Castillo UF, Strobel GA, Ford EJ, Hess WM, Porter H, Jensen JB, Albert H, Robison R, Condron MA, Teplow DB, Stevens D, Yaver D. Munumbicins, wide-spectrum antibiotics produced by Streptomyces NRRL 30562, endophytic on Kennedia nigriscans. Microbiol, 2002; 148:2675-2685.

Castillo U, Harper JK, Strobel GA, Sears J, Alesi K, Ford E, Lin J, Hunter M, Maranta M, Ge H, Yaver D, Jensen JB, Porter H, Robison R, Milar D, Hess WM, Condron M, Teplow D. Kakadumycins, novel antibiotics from Streptomyces sp NRRL 30566, an endophyte of Grevillea pteridifolia. FEMS Microbiol Lett 2003; 224:183-190.

Coombs JT, Franco CMM. Isolation and identification of actinobacteria from surface-sterilized wheat root. Appl Environ Microbiol, 2003; 69:5603-5608.

Fleck WF, Strauss DG, Prauser H. Naphthoquinone antibiotics from Streptomyces lateritius, fermentation, isolation and characterisation of granatomycins A, C and D. Z. Allg Mikrobiol, 1980; 20:543-551.

Germaine K, Keogh E, Garcia-Cabellos G, Borremans B, van der Lelie D, Barac T, Oeyen L, Vangronsveld J, Moore FP, Moore ER, Campbell CD, Ryan D, Dowling DN. Colonisation of poplar trees by $g f p$ expressing bacterial endophytes. FEMS Microbiol Ecol, 2004; 48:109118.

Gordon RE, Barnett DA, Handerhan JE, Pang CHN. Nocardia coeliaca, Nocardia autotrophica and the Nocardin strain. Int J Syst Evol Microbiol, 1974; 24:54-63.

James PDA, Edwards C. The effects of temperature on growth and production of the antibiotic granaticin by a thermotolerant Streptomycete. J Gen Microbiol, 1989; 135:1997-2003.

Kumar A, Patil D, Rajamohana PR, Ahamad A. Isolation, Purification and Characterization of Vinblastine and Vincristine from Endophytic Fungus Fusarium oxysporum Isolated from Catharanthus roseus. 2013; PLoS ONE 8: e71805. doi:10.1371/journal.pone.0071805

Kharwar, R.N., Verma, V.C., Strobel, G., and Ezra, D., 2008. The endophytic fungal complex of Catharanthus roseus (L.) G. Don. Curr. Sci. 95: 228-233

Kimura MA. Simple method for estimating evolutionary rate of base substitutions through comparative studies of nucleotide sequences. $\mathbf{J}$ Mol Evol, 1980; 16:111-120.

Maehr H, Cuellar HV, Smallheer J, Williams TH, Sasso GJ, Berger J. Microbial products. II. Granaticinic acid, a new antibiotic from a thermophilic streptomycete. Monatsh Chem, 1979; 110:531 -540.

Saitou N, Nei M. The neighbor-joining method: A new method for reconstructing phylogenetic trees. Mol Biol Evol, 1987; 4:406-425.

Santhi VS, Solomon RDJ. Phylogenetic analysis and antimicrobial activities of Streptomyces isolates from mangrove sediment. J Basic Microbiol, 2011; 51:71-79.

Shirling EB, Gottlieb D. Methods for characterization of Streptomyces species. Int J Syst Bacteriol, 1966; 16:313-340.

Stierle A, Strobel G, Stierle D. Taxol and taxane production by Taxomyces andreanae, an endophytic fungus of Pacific Yew. Science, $1993 ; 260: 214-216$.

St. Pyrek JS, Achmatowicz O, Zamojski A. Naphtho- and anthraquinones of Streptomyces thermoviolaceous WR14, Structure and model synthesis. Tetrahedron, 1977; 33:673-680.

Strobel GA. Endophytes as sources of bioactive products. Microbes Infect. 2003; 5, 535-544. Strobel G, Daisy B. Bioprospecting for microbial endophytes and their natural products. Microbiol Mol Biol Rev, 2003; 67:491-502.

Taechowisan T, Lu C, Shen Y, Lumyong S. Secondary metabolites from endophytic Streptomyces aureofaciens CMUAc130 and their antifungal activity. Microbiol, 2005; 151:1691-1695.

Taechowisan T, Chanaphat S, Ruensamran W, Phutdhawong WS. Antibacterial activity of new flavonoids from Streptomyces sp. BT01; an endophyte in Boesenbergia rotunda (L.) Mansf. J Appl Pharmaceutic Sci, 2014; 4:8-13. DOI: 10.7324/JAPS.2014.40402

Tamura K, Dudley J, Nei M, Kumar S. MEGA4: Molecular Evolutionary Genetics Analysis (MEGA) software version 4.0. Mol Biol Evol, 2007; 124:1596-1599.

Williams ST, Goodfellow M, Alderson G, Wellington EMH, Sneath PHA, Sackin MJ. Numerical classification of Streptomyces and related taxa. J Gen Microbiol, 1983; 129:1743-1813.

How to cite this article:

Sudipta Roy, Debdulal Banerjee. Broad spectrum antibacterial activity of granaticinic acid, isolated from Streptomyces thermoviolaceus NT1; an endophyte in Catharanthus roseus (L.) G. Don. J App Pharm Sci, 2015; 5 (07): 006-011. 